\title{
RESULTS OF FIELD STUDIES ON NITROGEN AND PHOSPHORUS INPUT FROM AGRICULTURAL PRODUCTION TO SELECTED WATER BODIES IN WESTERN DVINA
}

\author{
Alexander Briukhanov ${ }^{1}$, Leonid Alexeev ${ }^{2}$, Natalia Oblomkova ${ }^{1}$, Igor Subbotin ${ }^{1}$ \\ ${ }^{1}$ Institute for Engineering and Environmental Problems in Agricultural Production, Russia; ${ }^{2}$ State \\ Hydrological Institute, Russia \\ sznii@yandex.ru
}

\begin{abstract}
In 2017 a field study of water bodies in Nevel and Usvyatsky Districts of Pskov Region was aimed to give qualitative and quantity estimation of the impact of local large-scale pig enterprises on the status of water bodies in the Western Dvina river basin. Water samples were taken and the flow was measured on the vulnerable areas and outside the farm impact area in accordance with an elaborated programme and methods of field measurements. Soil samples were collected from the fields, where liquid pig manure was applied. The results showed that on the local level, in the vicinity of these fields, the water bodies featured high levels of main manure pollution indicators - ammonium nitrogen and phosphorous. The concentration of ammonium varied from 4.4 to $32.7 \mathrm{mg} \cdot \mathrm{l}^{-1}$ at these points that was several hundred times higher than that in water bodies in natural areas; the concentration of dissolved phosphorus varied from 0.11 to $0.23 \mathrm{mg} \cdot 1^{-1}$ that was several times higher than the background values. The concentration of these elements was dropping down to the background level with the distance from the fields as the result of self-purification and dilution processes owing to natural conditions, associated mainly with the presence of wetlands.
\end{abstract}

Keywords: nitrogen, phosphorous, pollution, pig industry, Western Dvina.

\section{Introduction}

The main branch of agricultural production, which has development prospects on the territories in the Western Dvina River basin, is animal farming, which contributes to an increase in nutrient diffuse load. The mass of gross nitrogen and phosphorus in organic fertilisers applied in 2016 amounted to 4,510 tons and 1,023 tons, respectively. Taking into account the planned increase in the animal stock and, consequently, the yield of manure, the gross nitrogen mass will be $5705 \mathrm{t}$ per year and the gross phosphorus - $1333 \mathrm{t}$ per year at the projected level of 2020 [1]. The growth in manure volumes leads to higher amount of nitrogen and phosphorus and, accordingly, to bigger area of agricultural land needed for application of all the resulting organic fertilisers.

Major agricultural facilities, pig rearing complexes included, which generate large masses of liquid manure, are a particular threat to environmental security and the level of diffuse load on the Russian part of the territory under investigation. Pig rearing complexes apply modern animal housing practices and manure removal technologies (mainly gravity systems), which produce the manure with 93-96\% moisture content, 2.3-2.5 kg.t $\mathrm{t}^{-1}$ nitrogen content and $0.6-0.8 \mathrm{~kg} \cdot \mathrm{t}^{-1}$ phosphorus content [2]. Currently, within the boundaries of the Russian part of the Western Dvina catchment area, there are 9 production sites with intensive pig rearing, where 267021 pigs are housed at any one time [3], which can be expressed as 80 thousand livestock units. Even if all agricultural areas in the municipal districts where pig complexes are situated will be used, the animal density will be approximately 23 livestock units per hectare - significantly higher than for other large enterprises in the Baltic Sea region [4].

IEEP methodology was used to estimate diffuse nutrient load from agriculture to waterbodies in the Russian part of the Western Dvina catchment area [5]. Annual nitrogen and phosphorous loads from agriculture production to the water objects in Pskov Region within Western Dvina catchment area are 76 ton of nitrogen and 11 ton of phosphorous. It should be noted that within the methodology it is assumed that all manure is evenly applied and there is significant uptake with yields. However, taking into account that there is lack of areas for application of all manure produced by pig complexes, the possibility of additional negative impact, not included in the methodology, should be investigated.

To assess the pollution risk of water bodies by the waste from large-scale pig complexes a series of field studies on individual watercourses was conducted in Usvyatsky $\left(457 \mathrm{~km}^{2}\right.$ within Western Dvina catchment) and Nevelsky (1400 $\mathrm{km}^{2}$ within Western Dvina catchment) Districts of Pskov Region, which are the areas with the highest concentration of pig farms.

\section{Materials and methods}

The field studies included the following tasks: 
- preconnaissance survey of the territories adjacent to large-scale pig complexes in Nevelsky and Usvyatsky Districts to specify the zone of possible exposure to nutrient loading from the facilities of developing pig complexes located in the watershed of the Western Dvina and Lovat River basins;

- determining the presence of natural water bodies in the surveyed area, not associated with the livestock complexes and other possible objects of anthropogenic load with the aim to use them as reference (background);

- random measurements of water flow in the watercourses adjacent to the territory of pig complexes and capable of receiving the point source waste water and non-point wastewater from manure storage facilities;

- sampling of water to measure the nitrogen, potassium and phosphorus content in the above watercourses.

The field studies were performed from 8 to 10 August 2017 by two teams - from the Institute for Engineering and Environmental Problems in Agricultural Production (IEEP) and from the State Hydrological Institute (SHI).

After processing of cartographic materials and space images, the points for water sampling and water flow measurements were identified. Tables 1 and 2 include coordinates of sampling points for IEEP team and SHI.

To take into account the regional peculiarities of the nutrient content in natural waters, both field groups determined the content of these substances in transboundary rivers Ushcha and Usvyacha, as well as in forest streams, presumably not affected by pig complexes.

IEEP field group collected water and soil samples, some of which were analysed in the field; others were preserved and sent for further analysis to the IEEP laboratory. Chemical analysis of water samples was carried out using certified methods.

SHI team was engaged in hydro-ecological examination of water objects, including water sampling and water flow measurements.

\section{Results and discussion}

Table 1 presents the results of water flow measurements by SHI team.

Table 1

Position of water sampling points and flow measurements made by SHI team

\begin{tabular}{|c|c|c|c|c|}
\hline \multirow{2}{*}{ Date } & \multirow{2}{*}{ Water body } & \multicolumn{2}{|c|}{ Position data, degree } & \multirow{2}{*}{$Q, \mathrm{~m}^{3} \cdot \mathrm{s}^{-1}$} \\
\hline & & latitude & longitude & \\
\hline \multirow{5}{*}{08.08} & $\begin{array}{l}\text { Untitled stream from irrigation fields near } \\
\text { Tretiakovo Village }\end{array}$ & $56^{\circ} 01^{\prime} 45.4^{\prime \prime}$ & $29^{\circ} 44^{\prime} 08.2^{\prime \prime}$ & 0.0038 \\
\hline & Vonstva River - Velikoje Selo & $56^{\circ} 00^{\prime} 21.0^{\prime \prime}$ & $29^{\circ} 41^{\prime} 57.8^{\prime \prime}$ & 0.172 \\
\hline & Ushcha River - Turki Perevoz & $56^{\circ} 03^{\prime} 00.8^{\prime \prime}$ & $29^{\circ} 32^{\prime} 25.4^{\prime \prime}$ & 7.95 \\
\hline & $\begin{array}{c}\text { Untitled stream from untitled lake flowing to } \\
\text { Ushcha River }\end{array}$ & $56^{\circ} 04^{\prime} 44.0^{\prime \prime}$ & $29^{\circ} 32^{\prime} 37.7^{\prime \prime}$ & 0.0026 \\
\hline & Ushchanka River - Talankino & $56^{\circ} 12^{\prime} 12.7^{\prime \prime}$ & $29^{\circ} 35^{\prime} 21.2^{\prime \prime}$ & 2.46 \\
\hline \multirow{8}{*}{09.08} & $\begin{array}{l}\text { Usvyacha River between Ozeron Lake and } \\
\text { Ordosno Lake }\end{array}$ & $56^{\circ} 01^{\prime} 45.3^{\prime \prime}$ & $30^{\circ} 57^{\prime} 24.9^{\prime \prime}$ & 2.18 \\
\hline & Usvyacha River - Titovo & $55^{\circ} 55^{\prime} 17.4^{\prime \prime}$ & $31^{\circ} 02^{\prime} 43.5^{\prime \prime}$ & 1.02 \\
\hline & Usvyacha River - Tserkovishche & $55^{\circ} 53^{\prime} 43.4^{\prime \prime}$ & $30^{\circ} 51^{\prime} 11.3^{\prime \prime}$ & 2.32 \\
\hline & $\begin{array}{c}\text { Untitled stream flowing to Uzmen Lake from } \\
\text { South-West }\end{array}$ & $55^{\circ} 44^{\prime} 21.8^{\prime \prime}$ & $30^{\circ} 42^{\prime} 36.4^{\prime \prime}$ & 0.0017 \\
\hline & $\begin{array}{c}\text { Watercourse from Uzhanye Lake to Bolshije } \\
\text { Glyshi Lake - Prudishche }\end{array}$ & $55^{\circ} 46^{\prime} 25.7^{\prime \prime}$ & $30^{\circ} 41^{\prime} 41.8^{\prime \prime}$ & 0.178 \\
\hline & \begin{tabular}{|c|} 
Uzmen River - Usvyaty \\
\end{tabular} & $55^{\circ} 44^{\prime} 44.1^{\prime \prime}$ & $30^{\circ} 43^{\prime} 48.3^{\prime \prime}$ & 0.523 \\
\hline & Usvyacha River - Karpenkino & $55^{\circ} 41^{\prime} 02.0^{\prime \prime}$ & $30^{\circ} 46^{\prime} 17.1^{\prime \prime}$ & 2.82 \\
\hline & Usvyacha River - Kozlovo & $55^{\circ} 45^{\prime} 29.0^{\prime \prime}$ & $30^{\circ} 47^{\prime} 42.9^{\prime \prime}$ & 2.46 \\
\hline
\end{tabular}


Table 1 (continued)

\begin{tabular}{|c|c|c|c|c|}
\hline \multirow{2}{*}{ Date } & \multirow{2}{*}{ Water body } & \multicolumn{2}{|c|}{ Position data, degree } & \multirow{2}{*}{$\boldsymbol{Q}, \mathbf{m}^{\mathbf{3}} \cdot \mathbf{s}^{-\mathbf{1}}$} \\
\cline { 2 - 4 } & latitude & longitude & \\
\hline \multirow{4}{*}{10.08} & Untitled stream - Antropovo & $55^{\circ} 45^{\prime} 47.0^{\prime \prime}$ & $30^{\circ} 47^{\prime} 37.5^{\prime \prime}$ & 0.0065 \\
\cline { 2 - 4 } & $\begin{array}{c}\text { Untitled stream from pig complex Blinki to } \\
\text { Zaverezhie Lake }\end{array}$ & $55^{\circ} 54^{\prime} 49.0^{\prime \prime}$ & $29^{\circ} 59^{\prime} 23.0^{\prime \prime}$ & 0.00 \\
\cline { 2 - 4 } & $\begin{array}{c}\text { Untitled stream from pig complex } \\
\text { Kosenkovo to Zaverezhie Lake }\end{array}$ & $55^{\circ} 54^{\prime} 34.4^{\prime \prime}$ & $29^{\circ} 58^{\prime} 19.1^{\prime \prime}$ & 0.082 \\
\cline { 2 - 5 } & Yezerishche Lake - Lobok & $55^{\circ} 52^{\prime} 18.6^{\prime \prime}$ & $29^{\circ} 58^{\prime} 39.9^{\prime \prime}$ & - \\
\cline { 2 - 5 } & Well b Kublanovo Village & $55^{\circ} 59^{\prime} 55.8^{\prime \prime}$ & $30^{\circ} 01^{\prime} 25.3^{\prime \prime}$ & - \\
\cline { 2 - 5 } & Lovat River - Polibino & $56^{\circ} 08^{\prime} 47.5^{\prime \prime}$ & $30^{\circ} 23^{\prime} 44.1^{\prime \prime}$ & 9.882 \\
\hline
\end{tabular}

The water flow measurement results (SHI data) show that the water flows in forest streams during the examination varied from 0 to $0.082 \mathrm{~m}^{3} \cdot \mathrm{s}^{-1}$; in Ushcha and Ushchanka Rivers - from 2.46 to $7.95 \mathrm{~m}^{3} \cdot \mathrm{s}^{-1}$; in Usvyacha River - from 1.02 to $2.82 \mathrm{~m}^{3} \cdot \mathrm{s}^{-1}$. It should be noted that the measurements took place in summer low water season under the lack of rains. Ushcha catchment area is $1707 \mathrm{~km}^{2}$; Usvyach is $1343 \mathrm{~km}^{2}$.

The water sampling was designed in such a way that the content of nutrients in the watercourses adjacent to the territory of enterprises could be compared with the concentrations of these components in the natural water bodies located at a significant distance from the objects with adverse impact. Location of the sampling points can be found in Figure 1. In addition, in order to assess the possibility of migration of these substances through the hydrographic network, the samples were taken in the water bodies located in the Uzmen Lake basin, at various distances from the fields irrigated with liquid pig manure. Sampling results from upstream cross-sections on Ushcha ans Usvyacha rivers (far from pig complexes), as well as on small forest rivers, unaffected by human activities, were used as reference background values.

Table 2

Description of sampling points (IEEP team data)

\begin{tabular}{|c|c|c|c|c|}
\hline \multirow{2}{*}{$\begin{array}{c}\text { Sampling } \\
\text { point } \\
\text { number } \\
\text { (IEEP) }\end{array}$} & \multicolumn{2}{|c|}{ Position data } & \multirow{2}{*}{$\begin{array}{l}\text { Sampling } \\
\text { date }\end{array}$} & \multirow{2}{*}{ Notes (sample type) } \\
\hline & latitude & longitude & & \\
\hline 1 & 56.029394 & 29.737572 & 08.08 .17 & $\begin{array}{c}\text { Area affected by pig complexes (Nevelsky } \\
\text { District) }\end{array}$ \\
\hline 2 & 56.016922 & 29.660258 & 08.08 .17 & $\begin{array}{c}\text { Area affected by pig complexes (Nevelsky } \\
\text { District) }\end{array}$ \\
\hline 3 & 56.050545 & 29.543058 & 08.08 .17 & $\begin{array}{c}\text { Background content (reference) (Nevelsky } \\
\text { District) }\end{array}$ \\
\hline 4 & 56.029258 & 30.956831 & 09.08 .17 & $\begin{array}{c}\text { Background content (reference) (Usvyatsky } \\
\text { District) }\end{array}$ \\
\hline 5 & 55.988579 & 31.059550 & 09.08 .17 & $\begin{array}{c}\text { Background content (reference) (Usvyatsky } \\
\text { District) }\end{array}$ \\
\hline 6 & 55.853768 & 30.778131 & 09.08 .17 & $\begin{array}{c}\text { Area affected by pig complexes (Usvyatsky } \\
\text { District) }\end{array}$ \\
\hline 7 & 55.860046 & 30.782244 & 09.08 .17 & $\begin{array}{l}\text { Background content (reference) (Usvyatsky } \\
\text { District, Uzhitsa River) }\end{array}$ \\
\hline 8 & 55.832372 & 30.732082 & 09.08 .17 & $\begin{array}{c}\text { (Uzhitsa river, around } 3 \mathrm{~km} \text { from the irrigation } \\
\text { fields of pig complexes) }\end{array}$ \\
\hline 9 & 55.819689 & 30.722065 & 09.08 .17 & $\begin{array}{l}\text { (Uzhitsa river, around } 6 \mathrm{~km} \text { from the irrigation } \\
\text { fields of pig complexes) }\end{array}$ \\
\hline 10 & 55.818169 & 30.721321 & 09.08 .17 & $\begin{array}{l}\text { Water from a well to assess the impact of pig } \\
\text { complexes on the groundwater }\end{array}$ \\
\hline
\end{tabular}


Table 2

\begin{tabular}{|c|c|c|c|c|}
\hline $\begin{array}{c}\text { Sampling } \\
\text { point } \\
\text { number } \\
\text { (IEEP) }\end{array}$ & \multicolumn{2}{|c|}{ Position data } & Sampling & Notes (sample type) \\
\cline { 2 - 4 } & latitude & longitude & & \\
\hline 11 & 55.818169 & 30.726028 & 09.08 .17 & Area affected by pig complexes \\
\hline 12 & 55.801103 & 30.713057 & 09.08 .17 & Area affected by pig complexes \\
\hline 13 & 55.766341 & 30.723893 & 09.08 .17 & Area affected by pig complexes \\
\hline 14 & 55.742148 & 30.692522 & 09.08 .17 & Area affected by pig complexes \\
\hline 15 & 55.745515 & 30.731625 & 09.08 .17 & $\begin{array}{c}\text { (water exchange between lakes - to assess the } \\
\text { impact of pig complexes) }\end{array}$ \\
\hline 16 & 55.831205 & 30.734398 & 10.08 .17 & Background content (reference) \\
\hline
\end{tabular}

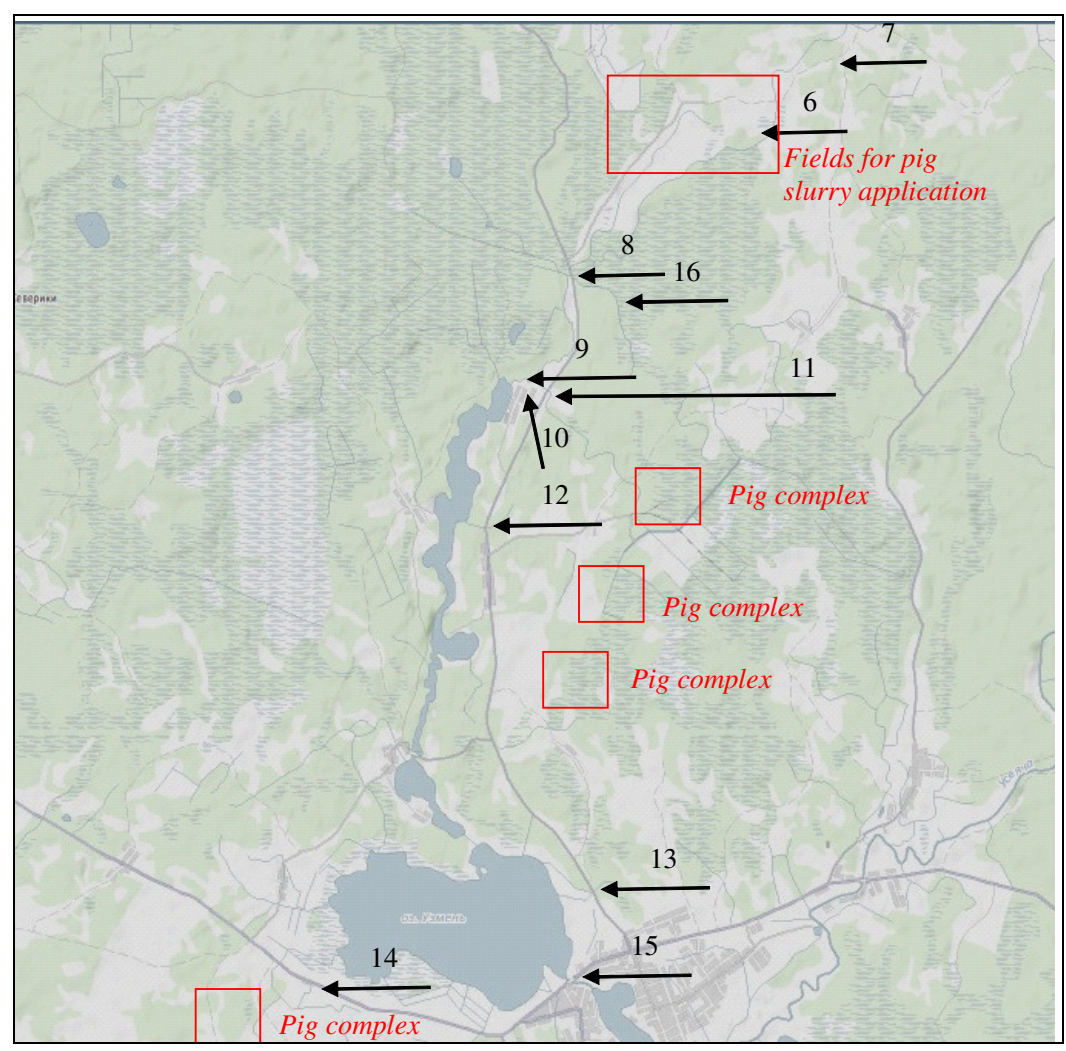

Fig. 1. Layout of sampling points in Uzhitsa River catchment

The effect of pig complexes was estimated by indicator substances associated with liquid pig manure pollution - ammonium nitrogen, phosphorus and potassium. The obtained results were compared with the maximum permissible concentration of pollutants (MPC) in fishery water objects [6] as well as with the average concentrations of these substances in background points (MPC is not established for potassium), as shown in Fig. 2-4.

The field study findings show that the chemical composition of water in the water bodies, located in the immediate vicinity of pig complexes and fields for manure (wastewater) spreading, differs from that in remote forest streams. As can be seen in Fig. 3 and 6, the samples from points 1, 2, 6, 9, 11, 12, and 14 have much higher content of ammonium nitrogen, nitrate nitrogen and potassium. In view of this, the significant impact of pig complexes on the nearby water bodies is verified. The quality of water in the well, located in the zone of possible pig complex impact, does not reveal the presence of groundwater contamination. 


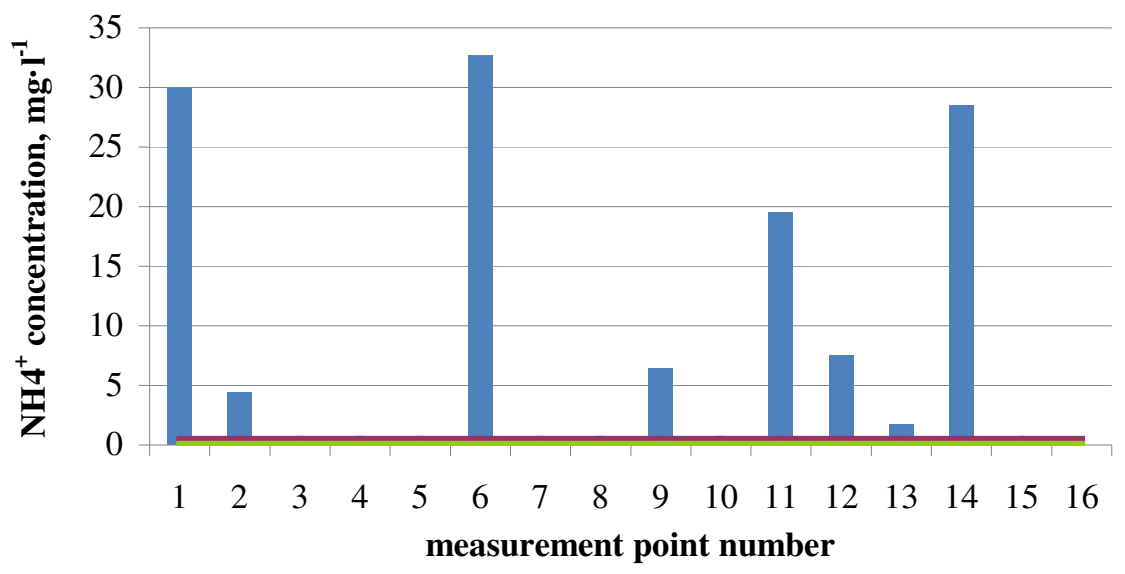

analysis results

MPC for fishery ponds

average background concentration

Fig. 2. Measured water concentration of ammonium ion: $\mathrm{MPC}=0.5 \mathrm{mg} \cdot \mathrm{l}^{-1}$

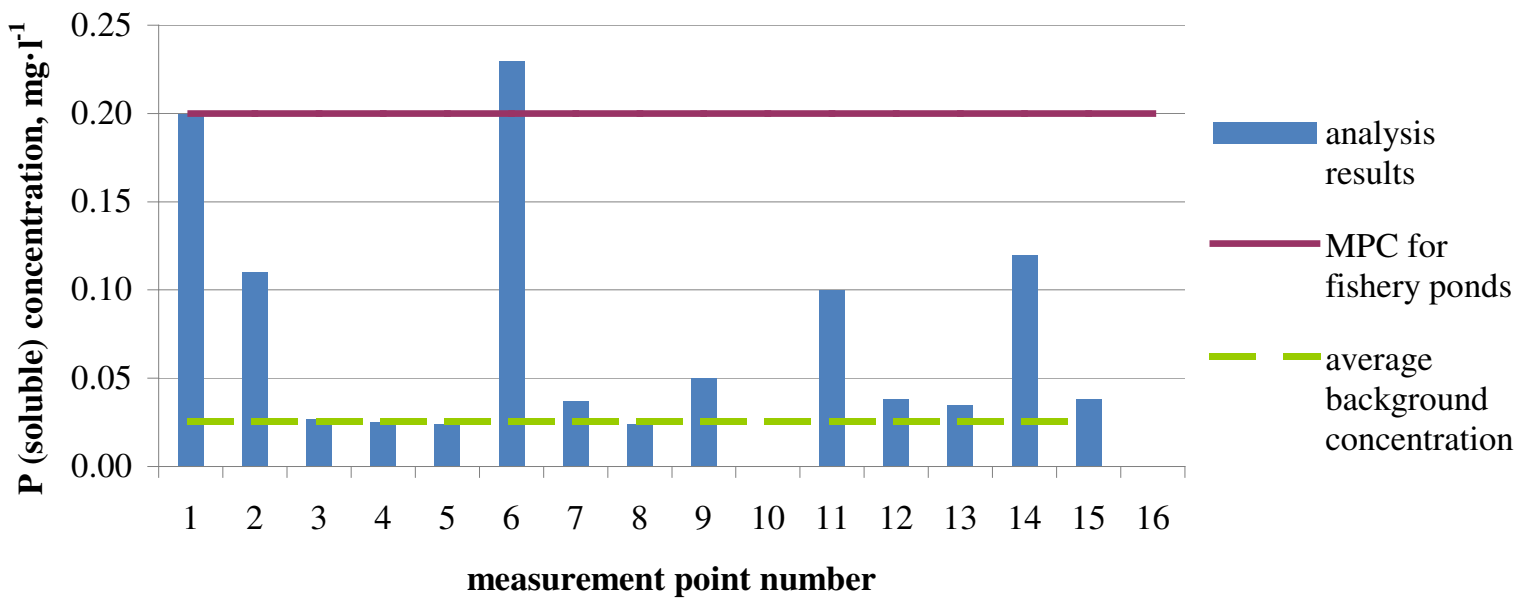

Fig. 3. Measured water concentration of soluble phosphorous: $\mathrm{MPC}=0.2 \mathrm{mg} \cdot \mathrm{l}^{-1}$; concentration hasn't been measured in $16^{\text {th }}$ point

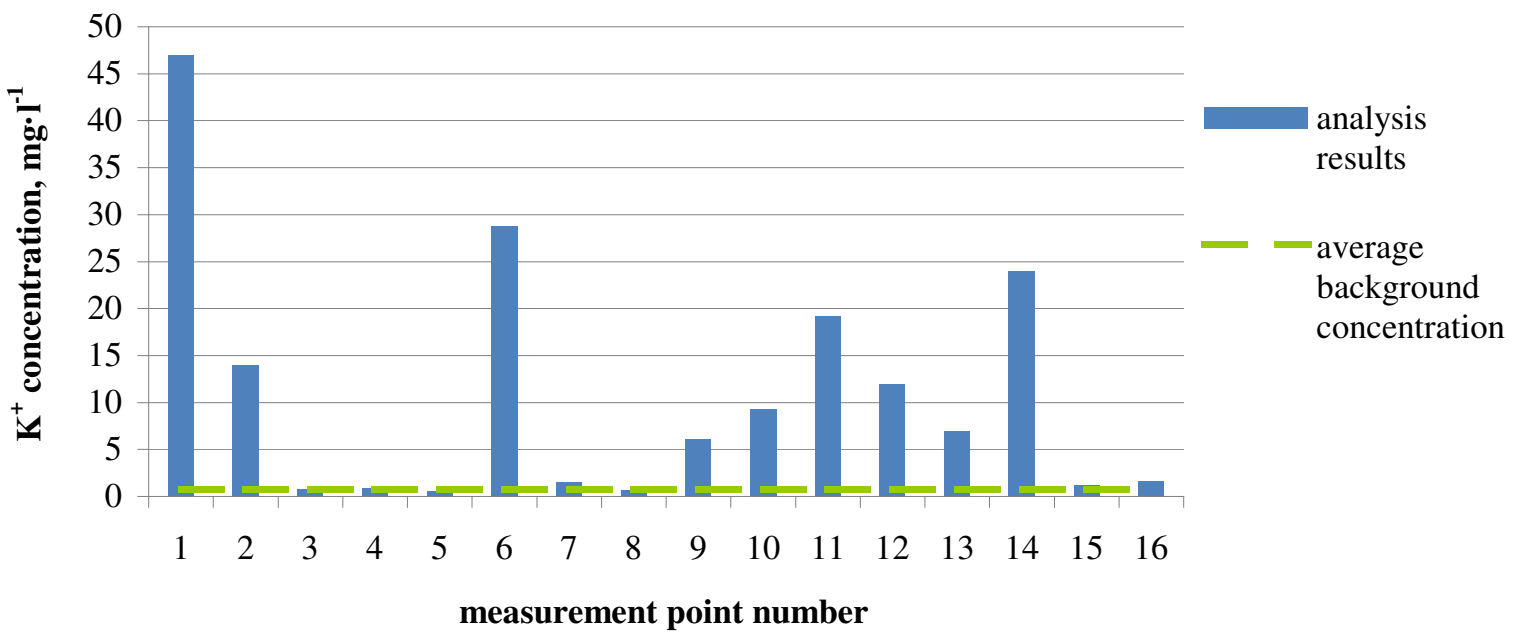

Fig. 4. Measured water concentration of potassium ion: MPC not established

Analysis of nutrients migration with the watercourse of Uzhitsa River, which is exposed to the effect of the fields in its middle course, showed that local pollution in the immediate vicinity of these objects significantly reduced just $3 \mathrm{~km}$ from them, both as a result of additional water supply with forest inflowing streams, and in connection with the possible water cleaning, when passing the swamps. In this respect, the quantity of swamps should be noted as a specific feature of the study area. 
The measurement results suggest that today the swamps act as a natural filter on the way of nutrients to the water bodies and reduce the nutrient content in the water to the natural background level.

It should be noted that at the time of survey, no manure was spread on the fields. The water flow in the lower course of Uzhitsa River was practically zero. It can be expected that manure spreading in wet weather conditions will significantly increase the range of nutrient migration with the water of Uzhitsa River.

The study also included the soil sampling on the fields, where manure was applied, which were located in Uzhitsa River basin and affected water sampling point No,6. The analysis results are shown in Table 3.

Table 3

Results of soil analysis (IEEP data)

\begin{tabular}{|c|c|c|c|c|c|c|c|c|}
\hline \multirow{2}{*}{$\begin{array}{c}\text { Sample } \\
\text { number }\end{array}$} & $\begin{array}{c}\text { Date of } \\
\text { sampling }\end{array}$ & $\begin{array}{c}\text { Moisture } \\
\text { content, \% }\end{array}$ & $\begin{array}{c}\mathbf{N}_{\text {total (in }} \text { terms of } \\
\mathbf{N H}_{\mathbf{4}}^{+} \text {) }\end{array}$ & $\mathbf{N H}_{\mathbf{4}}^{+}$ & $\mathbf{K}^{+}$ & $\begin{array}{c}\mathbf{P} \mathbf{( 0 . 2 N} \\
\mathbf{H C L})\end{array}$ & $\mathbf{P}_{\text {gross. }}$ & \multirow{2}{*}{ Notes } \\
\hline 1 & 10.08 .17 & 19.3 & 1466 & 26.80 & 202.3 & 225.2 & 872 & $\begin{array}{c}\text { Probably manure } \\
\text { was applied last } \\
\text { year }\end{array}$ \\
\hline 2 & 10.08 .17 & 24.4 & 1066 & 18.46 & 176.1 & 189.9 & 1680 & - \\
\hline 3 & 10.08 .17 & 35.9 & 2650 & 12.30 & 146.3 & 353.6 & 1570 & $\begin{array}{c}\text { A site with a lot of } \\
\text { pig manure in } \\
\text { hollows }\end{array}$ \\
\hline 4 & 10.08 .17 & 21.1 & 1066 & 13.4 & 211.4 & 197.7 & 754 & $\begin{array}{c}\text { Relatively recent } \\
\text { manure } \\
\text { application }\end{array}$ \\
\hline
\end{tabular}

The soil study showed that there was significant accumulation of nitrogen and phosphorus in the fields, where pig manure was applied; in the future this would result in a sharp increase in the input of nutrients to the nearby watercourses. For this not to happen, these farmlands need to be used reasonably and effectively, achieving maximum removal of nutrients with the harvested crops.

\section{Conclusions}

1. In all collected water samples in the area affected by the pig complexes, the concentrations of ammonium nitrogen significantly exceeded the MPC; relatively high concentrations of phosphorus were also found, almost 10 times exceeding the background levels that indicated the presence of significant local pollution with liquid pig manure in the vicinity of irrigation fields.

2. Analysis of nutrient migration with the waterways, affected by agricultural lands, showed that local pollution in the immediate vicinity of these sites significantly reduced in a few kilometres, both as a result of additional water inflow from the relatively clean tributaries and in connection with possible water self-cleaning. The swamps act as a natural barrier to the migration of nutrients from the soil spread with liquid pig manure. However, their accumulative capacity is difficult to assess, so this process must stay under control.

3. Substantial accumulation of nitrogen and phosphorus was registered in the fields, where pig manure was spread; in the future it could lead to a sharp increase in the supply of nutrients to the nearby watercourses.

\section{Acknowledgement}

The study was carried out within scientific project "Scientifically grounded predictive assessment of the impact of the nutrient load generated by diffuse agricultural sources on water management in Western Dvina river basin in the framework of Russian-Belarusian cooperation in the field of protection and rational use of transboundary water bodies". 


\section{References}

[1] Разработка научно-обоснованной прогнозной оценки воздействия биогенной нагрузки на водохозяйственную обстановку в бассейне реки Западная Двина в рамках российскобелорусского сотрудничества в области охраны и рационального использования трансграничных вод (Scientifically grounded predictive assessment of the impact of the nutrient load generated by diffuse agricultural sources on water management in Western Dvina river basin in the framework of Russian-Belarusian cooperation in the field of protection and rational use of transboundary water bodies). Interim report, State Hydrological Institute, 2017. 232 p. (In Russian).

[2] Management Directive for Agro-Industrial Complex "Recommended Practice for Engineering Designing of Systems for Animal and Poultry Manure Removal and Pre-application Treatment" РД-АПК 1.10.15.02-17, in force since 2017, 173 p. (In Russian).

[3] Федеральная служба государственной статистики (Federal Service of State Statistics) [online] [14.03.2017]. Available at: http://www.gks.ru/.

[4] Skorupski J. (ed.). 2013. Report on Industrial Livestock Farming in the Baltic Sea Region - environmental protection context. Coalition Clean Baltic. Uppsala

[5] Briukhanov A., Kondratyev S., Tarbaeva V., Vorobyeva E., Oblomkova N. Contribution of agricultural sources to nutrient load generated on the Russian part of the Baltic Sea catchment area. Proceedings of the 8th International Scientific Conference "Rural Development 2017: Bioeconomy Challenges", November 23-24, 2017, Kaunas, Lithuania, pp. 226-231

[6] Об утверждении нормативов качества воды водных объектов рыбохозяйственного значения, в том числе нормативов предельно допустимых концентраций вредных веществ в водах водных объектов рыбохозяйственного значения (On the approval of water quality standards for water bodies of fishery importance). Order of the Ministry of Agriculture of the Russian Federation on December 13, 2016 № 552 [online] [01.03.2017] Available at: http://publication.pravo.gov.ru/Document/GetFile/0001201701160006?type=pdf. 